\title{
Factors of influence on performance of heat power industry enterprise
}

\author{
Hennadii Karimov ${ }^{1 *}$, Kateryna Zvonarova ${ }^{1}$, and Ivan Karimov ${ }^{2}$ \\ ${ }^{1}$ Dniprovsk State Technical University, Department of Business Management and Administration, \\ 51918 Kamianske str. Dniprobudivska 2, Ukraine \\ ${ }^{2}$ Dniprovsk State Technical University, Department of Applied and Higher Mathematics, 51918 \\ Kamianske str. Dniprobudivska 2, Ukraine
}

\begin{abstract}
Research into the factors influencing the performance of heat power industry enterprise is specific due to aspects of subordination and regulation of enterprises in the field of heat power engineering. Heat power plant (thermal power plant) is a typical representative of the heat power industry and it displays all the main characteristics of the industry. The conclusions of the PEST-analysis characterize the general factors influencing the heat and electricity market, i.e. the market of the discussed enterprise. According to the conclusions of the SWOT-analysis the paper determines the priority areas of enterprise development. The main step towards the intensification of the enterprise performance is a project aimed at raising the connected thermal capacity that will allow to reduce production costs (increasing the workload on equipment), improve social welfare for the city (creating new jobs and improving the quality of home heating) and boost interest of investors in the enterprise (growing profitability).
\end{abstract}

\section{Introduction}

The main problems of the enterprise PJSC "Dniprovs'ka Combined Heat Power Plant" and ways to tackle them are typical for enterprises of heat and power industry of Ukraine [1]. The main problem of JSC DCHP is that it is lacking current assets, including money funds. This fact is due to the following reasons: tariffs for heat production approved by the National Commission for State Regulation of Energy and Utilities [2] and significant debts of the customer - reseller of heat energy - the Municipal Utility Company of Kamianske City Council. This, in turn, has led to late payments for tax liabilities and natural gas. As a result, there were applied significant financial penalties, not having a source of funding, which results in the lack of financial resources to enable investment and current activities. The second (internal) problem is downtime of equipment, inefficient use of enterprise capacity. To solve this problem, the company needs to increase output, which is possible only by increasing consumption, i.e. by conquering new markets.

\footnotetext{
* Corresponding author: gkarimov@ukr.net
} 


\section{The combined heat and power plant in the town's infrastructure}

The company is a producer of electricity and heat in Kamianske. The main activities are: production, transmission and supply of heat and electricity to housing as well as to communal and industrial enterprises of the right bank of the city. In particular, the company provides:

- heat to housing and communal services and enterprises of the right-bank part of the city;

- electricity via overhead lines of the settlements of Petrykivka district, the left-bank residential area and the industrial zone of the city, provides power to a part of the Dniprovs'ky metallurgical plant.

The reliable performance of the enterprise during the whole period of operation allowed it to become an integral part of the social infrastructure of the city. The system of electric networks can fully meet the needs of the city in electric energy given that generating capacities of the Dniprovs'ka CHP are disconnected. As a source of electricity, CHP plays an important role as the source close to consumers and reliable for providing electricity to the city in emergency situations in power grids. In the "regular" modes, the production of electricity at CHP is not economically feasible due to its high cost. Based on this, the electric power of the CHP is not the main factor in choosing the design of existing equipment.

Currently, the company is the main source of heat for the right bank of the city. At the same time, there is a need to increase production in order to load equipment. The solution to this issue may be to enter a new market, i.e. to supply heat energy to the left bank of the city. However, any enterprise in the heat power industry is strongly influenced by- the environment, over which the company itself has no control. Environmental factors of the enterprise and their impact on the enterprise are grouped in table 1. Table 1 shows that the company is influenced by external factors that negatively affect the functioning of the enterprise as a whole.

Table 1. The factors of business environment.

\begin{tabular}{|c|c|c|}
\hline Factor & Description & Impact on the enterprise \\
\hline $\begin{array}{l}\text { The state of } \\
\text { the country's } \\
\text { economy }\end{array}$ & $\begin{array}{l}\text { The country's economy is in a deep } \\
\text { crisis. } \\
\text { Low external and domestic demand } \\
\text { due to the slowdown in economic } \\
\text { growth. } \\
\text { Decrease in purchasing power of } \\
\text { the population due to decrease in } \\
\text { real incomes. }\end{array}$ & $\begin{array}{l}\text { Decrease in electricity, gas, steam and } \\
\text { conditioned air supply (throughout the } \\
\text { industry) [3]. } \\
\text { Increase in receivables of the enterprise }\end{array}$ \\
\hline $\begin{array}{l}\text { Political and } \\
\text { legislative }\end{array}$ & $\begin{array}{l}\text { Changes in legislation relating the } \\
\text { market of electric energy }[4,5]\end{array}$ & $\begin{array}{l}\text { Changes in the system of market } \\
\text { relations. } \\
\text { Product price control }\end{array}$ \\
\hline $\begin{array}{l}\text { Technological } \\
\text { change }\end{array}$ & $\begin{array}{l}\text { Development of alternative } \\
\text { methods of heating and electricity } \\
\text { production [6] }\end{array}$ & Falling demand on CHP produce \\
\hline $\begin{array}{l}\text { Natural } \\
\text { environment }\end{array}$ & $\begin{array}{l}\text { Deterioration of the ecological state } \\
\text { of the environment. } \\
\text { Rising energy costs }\end{array}$ & $\begin{array}{l}\text { Release of chemicals into the } \\
\text { atmosphere, which demands to refurbish } \\
\text { the enterprise into a more } \\
\text { environmentally friendly one. } \\
\text { The increase of the cost of production of } \\
\text { the enterprise. } \\
\begin{array}{l}\text { Dependence of the enterprise's } \\
\text { production on gas supplies }\end{array}\end{array}$ \\
\hline
\end{tabular}




\section{General factors of influence on the enterprise's market}

The main factors influencing the electricity market, i.e. the enterprise market are analyzed using PEST-analysis. The conclusions of the PEST-analysis allow outlining the strategic directions of development of the thermal power plant. The impact of each factor can be estimated within the scale from 1 to 3 . According to the method described in [7], figure 1 denotes a small level of influence of the factor; the work of the organization almost does not change under the influence of the factor; 2 - the figure indicating that the activities of the enterprise can be affected only by significant changes in the factor; 3 - the figure indicating that the factor is able to significantly affect the functioning of the enterprise, with any fluctuations of the factor changing the performance of the enterprise (Table 2).

Table 2. Analysis of the enterprise's market.

\begin{tabular}{|c|c|c|c|}
\hline Factor & $\begin{array}{c}\text { Significance } \\
\text { of impact }\end{array}$ & $\begin{array}{l}\text { Effect on the } \\
\text { company } \\
\text { performance }\end{array}$ & Related response of the enterprise \\
\hline \multicolumn{4}{|c|}{ POLITICS } \\
\hline $\begin{array}{l}\text { The Law of } \\
\text { Ukraine «On the } \\
\text { market of electric } \\
\text { energy» }\end{array}$ & 3 & $\begin{array}{l}\text { A shift in market } \\
\text { relations }\end{array}$ & $\begin{array}{l}\text { Consolidation of its position on the } \\
\text { market, search for new distribution } \\
\text { channels, conquering new market } \\
\text { niches }\end{array}$ \\
\hline $\begin{array}{l}\text { Studying the } \\
\text { project of } \\
\text { constructing new } \\
\text { boiler houses at } \\
\text { the local level }\end{array}$ & 3 & $\begin{array}{l}\text { Redundancy of the } \\
\text { enterprise and its } \\
\text { complete } \\
\text { liquidation }\end{array}$ & $\begin{array}{l}\text { Reduction of output prices, due to the } \\
\text { achievement of the nominal load on } \\
\text { the equipment, the entrance into the } \\
\text { left-bank part of the city }\end{array}$ \\
\hline \multicolumn{4}{|c|}{ ECONOMY } \\
\hline Economic crisis & 2 & $\begin{array}{l}\text { Reduction of } \\
\text { supply volumes }\end{array}$ & $\begin{array}{l}\text { Maintaining the financial capacity of } \\
\text { the enterprise, seeking new } \\
\text { distribution opportunities }\end{array}$ \\
\hline $\begin{array}{l}\text { Rising natural gas } \\
\text { costs }\end{array}$ & 2 & $\begin{array}{l}\text { Raising product } \\
\text { prices; } \\
\text { Increase in } \\
\text { accounts payable }\end{array}$ & $\begin{array}{l}\text { Searching and implementing ways of } \\
\text { price reduction for enterprise } \\
\text { products }\end{array}$ \\
\hline $\begin{array}{l}\text { Seasonal impact } \\
\text { (effect of the } \\
\text { environment) }\end{array}$ & 2 & $\begin{array}{l}\text { Equipment } \\
\text { downtime, losses }\end{array}$ & $\begin{array}{l}\text { Proposal to restore hot water supply } \\
\text { to customers }\end{array}$ \\
\hline $\begin{array}{l}\text { Governmental } \\
\text { control over } \\
\text { tariffs }\end{array}$ & 1 & $\begin{array}{l}\text { Declining } \\
\text { competitiveness }\end{array}$ & $\begin{array}{l}\text { Reduction of the price share } \\
\text { controlled by the enterprise }\end{array}$ \\
\hline \multicolumn{4}{|c|}{ SOCIAL AND CULTURAL FACTORS } \\
\hline $\begin{array}{l}\text { Declining } \\
\text { capacity to pay } \\
\text { for services }\end{array}$ & 1 & $\begin{array}{l}\text { Increase in } \\
\text { receivables }\end{array}$ & $\begin{array}{l}\text { Reducing the cost of heating by } \\
\text { achieving nominal load on the } \\
\text { equipment }\end{array}$ \\
\hline $\begin{array}{l}\text { Giving up central } \\
\text { heating }\end{array}$ & 2 & $\begin{array}{l}\text { Loss of production } \\
\text { volume }\end{array}$ & $\begin{array}{l}\text { Offering better services, bringing } \\
\text { down heating costs }\end{array}$ \\
\hline \multicolumn{4}{|c|}{ TECHNOLOGIES $[8]$} \\
\hline $\begin{array}{l}\text { Installing heat } \\
\text { meters }\end{array}$ & 1 & $\begin{array}{l}\text { Monitoring the } \\
\text { final result } \\
\text { (payment, volume } \\
\text { of consumption) }\end{array}$ & $\begin{array}{l}\text { Identifying transportation losses (if } \\
\text { any) and eliminating them, } \\
\text { monitoring the actual heat } \\
\text { consumption }\end{array}$ \\
\hline $\begin{array}{l}\text { Advantages of } \\
\text { alternative heating } \\
\text { equipment }\end{array}$ & 1 & $\begin{array}{l}\text { Decrease in } \\
\text { demand for the } \\
\text { enterprise products }\end{array}$ & $\begin{array}{l}\text { Offering more interesting conditions } \\
\text { for consumers (heating + hot water) }\end{array}$ \\
\hline
\end{tabular}


Table 2 shows that the strategic direction of development for CHP should be enlarging its market niche by connecting the left-bank part of the city to central heating. This makes it possible to defend the strategic position of the company in the city and deliver to consumers' apartments not only heating and electricity, but also hot water. The left-bank district is fully equipped with a heating system, which can potentially be a heat carrier in the form of hot water of appropriate parameters from the thermal power plant

Below presented are the specific characteristics of the market for the electricity industry: climate - temperate-continental, climatic region 3; the average outside air temperature for the heating period will be $-2^{\circ} \mathrm{C}$; the duration of the heating period will be 175 days; heat load from consumers of the district $210 \mathrm{Gcal} / \mathrm{h} .:$ heating and ventilation $172 \mathrm{Gcal} / \mathrm{h}$, hot water supply $-38 \mathrm{Gcal} / \mathrm{h}$. The right-bank part of the city is larger in area, the industrial potential here is significant and the city's housing area here is quite vast. The left-bank district is a concentration of multi-storey residential buildings. The total area of residential buildings in the left-bank district is 1659868 thousand $\mathrm{m} 2$, population -87.4 thousand people $[9,10]$. Thus, the implementation of the project for the supply of heating and hot water to the left bank of the city will allow the company to gain a foothold in the market and improve its financial condition.

\section{The position of the enterprise on the market}

In order to study the enterprise as an economic system in a particular market environment, one can apply SWOT analysis. Based on the methodology [11] Table 3 has been compiled which will help identify priority areas for the development of recommendations.

Table 3. Analysis of CHP in market environment.

\begin{tabular}{|c|c|c|}
\hline \multirow{8}{*}{ 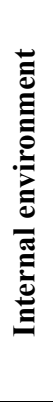 } & Strengths & Weaknesses \\
\hline & 1. Doesn't have competitors in the town & 1. Outdated equipment \\
\hline & $\begin{array}{l}\text { 2. Awareness of the market, well- } \\
\text { developed distribution system }\end{array}$ & 2. Non-efficient production technology \\
\hline & 3. Efficient organizational system & 3. Narrow production line \\
\hline & 4. Strategically important for the country & $\begin{array}{l}\text { 4. Unsatisfactory competitive position in } \\
\text { the country }\end{array}$ \\
\hline & & 5. High production costs \\
\hline & & 6. Unstable financial position \\
\hline & & 7. Incomplete equipment utilization \\
\hline \multirow{5}{*}{ 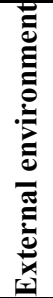 } & Opportunities & Threats \\
\hline & 1. Purchasing new equipment & 1. Unfavorable government policy \\
\hline & 2. Introducing new technology & 2. Dependency on natural gas prices \\
\hline & $\begin{array}{l}\text { 3. Marketing research to explore new } \\
\text { distribution channels }\end{array}$ & 3. Seasonal demand on production \\
\hline & $\begin{array}{l}\text { 4. The possibility of supplying hot water } \\
\text { to the consumer }\end{array}$ & 5. Falling demand on production \\
\hline
\end{tabular}

According to the results in table 3 , the following conclusions can be drawn:

1. Field of strengths and opportunities

- Based on its national strategic importance and significance for the town, one could initiate financial assistance from the state for the implementation of new projects;

- Relying on the market awareness it is possible to improve the distribution system as well as conquer a new market niche.

2. Field of strengths and threats 
- Well-developed distribution system serves as a basis for strengthening demand (additional hot water supply);

- The strategic importance of the enterprise for the country will improve the impact of government policy;

- Effective organizational system will reduce unnecessary costs in seasonal demand (reduction of working hours in the summer).

3. Field of weaknesses and opportunities

- Acquisition of new equipment and introduction of new technologies will reduce production costs, thus improving the financial condition of the enterprise;

- Marketing research will expand the production line and new distribution channels;

- Reducing production costs by increasing the load on the equipment.

Thus, the project to connect the left-bank part of the city to the central heating of the enterprise will not only reduce the input costs, but also to assert its importance for the town and increase investor interest in the enterprise. It is estimated that if the project is launched, the combined thermal capacity will be $454.8 \mathrm{Gcal} / \mathrm{h}$. [12], which will load the equipment almost completely, leading to increased workload on the equipment and reduce the production costs.

\section{Conclusion}

Consequently, the implementation of the project to connect the left-bank part of the city to the central heating system of PJSC "Dniprovs'ka CHP" will provide: improved quality and reliability of heat supply of the left-bank part of the city; rational use of equipment; increase in electricity generation with heat consumption; improved technical and economic performance of the enterprise; almost nominal efficiency of CHP; keeping tariffs for thermal energy stable for a long time. At the same time, when making a decision, one should take into account:

- Risks associated with the project: rising fuel prices - coal, natural gas; rising prices for equipment as well as construction and installation work; changing environment on electricity market; consumers' refusal to use thermal energy (individual heating or modular boiler rooms); refusal of the energy market to purchase electricity due to cheaper offer from other producers.

- Benefits from the project: redundancy of the left-bank boiler house; reduction of costs for transportation of thermal energy; heat tariffs for city residents will remain at the current level for a long time.

- Risk arising in case of rejection of the project: a reduction in product output and further deterioration of the financial state of the enterprise; efficiency will remain lower than nominal, which leads to unsustainable use of heat-generating properties of fuel and its overconsumption.

\section{References}

1. H. Karimov, K. Zvonarova, in Proceedings of the 2nd International Scientific Conference Eastern European Conference of Management and Economics: Environmental Management and Sustainable Economic Development, Ljubljana, 2020, ed. by L. Weis, V. Koval, K. Aškerc.

2. Verkhovna Rada of Ukraine, Law of Ukraine on the national energy and public utilities regulatory commission № 1540-VIII, Vidomosti Verkhovnoyi Rady Ukrayiny 51, 833 (2016) 
3. Group DTEK, Intehrovanyi zvit 2018: Ohliad haluzei ta makroekonomichnykh pokaznykiv Ukrainy (Integrated report 2018: Financial and non-financial results). (DTEK, Kyiv, 2019)

4. Verkhovna Rada of Ukraine, Law of Ukraine on the principles of functioning of the market of electric energy of Ukraine № 663-VII, Vidomosti Verkhovnoyi Rady Ukrayiny 22, 1781 (2014)

5. Verkhovna Rada of Ukraine, Law of Ukraine on the market of electric energy № 2019-VIII, Vidomosti Verkhovnoyi Rady Ukrayiny 27-28, 312 (2017)

6. Verkhovna Rada of Ukraine, Law of Ukraine on alternative energy sources № 555-IV, Vidomosti Verkhovnoyi Rady Ukrayiny 24, 155 (2003)

7. E. V. Spiridonova, Modern scientific researches and innovations 3(71), 81 (2017)

8. Research \& design center for development of the IPS of Ukraine, Ohliad analitychnykh robit mizhnarodnykh enerhetychnykh orhanizatsii shchodo stanu ta stsenariiv rozvytku svitovoi enerhetychnoi sfery $z$ prohnozom investuvannia $v$ enerhoefektyvnist (Review of analytical works of international energy organizations on the state and scenarios of development of the world energy sphere with the forecast of investment in energy efficiency). (RDCD IPS of Ukraine, Kyiv, 2018)

9. Economic development department of the Dniprodzerzhynsk city council, Stratehiia rozvytku mista Dniprodzerzhynsk na period do 2020 roku (Strategy of development of the city of Dniprodzerzhynsk for the period till 2020). (Dniprodzerzhynsk city council, Dniprodzerzhynsk, 2014)

10. Economic development department of the Kamyansk city council, Stratehiia rozvytku mista Kamianske na period do 2027 roku (Strategy of development of the city of Kamyanske for the period till 2027). (Kamyansk city council, Kamyanske, 2020)

11. L.V. Nosonova, Global and National Problems of Economy 4, 506 (2015)

12. Joint-stock company "Dniprovs'ka combine heat power plant" (2010), https://dtec.com.ua/documents. Accessed 15 Mar 2021 